\title{
Scrutinising The Production Of Space On The Example Of Regent Street and Painting A Modern Life By The Agencies Of Regency \\ * Dr. Hidayet Softaoğlu
}

Royal Central School of Speech and Drama, MA Scenography Graduate, London, UK

'Email: hidayet.tile@gmail.com

\section{ARTICLE INFO:}

Article history:

Received 8 November 2018

Accepted 3 January 2019

Available online 11 August 2019

\section{Keywords:}

Regent Street;

Production of Space;

Actor-Network

Theory,

Urban Mapping.

\begin{abstract}
A B S T R A C T
The main aim of this study is to analyse the production of space and how human and non-human entities function as space producers or devices. The scope of this study is the Regent Street from 1818 to 1848. This paper aims to answer the following question: could space be a product that we can produce or what other things involved in this production process? Numerous theorists contribute to the spatial analyses of this historical research. This paper puts special emphasis on the Lefebvrian spatial triad as a methodological decoder along with the Actor-Network Theory (ANT) to analyse the 19th century-Regent Street. The combination of the triad, as well as the $A N T$, will be deployed as an original tool to analyse spaces with their data; then they will be used to create a spatial map. To do so, visual and written sources will also be used as data to decode and re-map or re-paint the modern life of Regent Street during the Regency Period.
\end{abstract}

JOURNAL OF CONTEMPORARY URBAN AFFAIRS (2019), 3(3), 51-66.

https://doi.org/10.25034/ijcua.2019.v3n3-5

\section{This work is licensed under a Creative Commons Attribution - NonCommercial - NoDerivs 4.0. "CC-BY-NC-ND"

\section{Introduction}

London is a striking place as it went through a rapid social transformation because of its quick adaptation to the machinery following the Industrial Revolution. Especially, the Regency period (1811-30) displayed a fascinating range of art, architecture, and literature. Considering the fact that the city of London had never been changed even due to the Great Fire of London (1666) until the Regency period, this was the first time in the history of London; the plan of the city was amended to design the Regent Street.

The dictionary meaning of the term "production" is described as the "the process of making or growing goods to be sold or the amount of something that is made or grown by a country or a company".

\section{*Corresponding Author:}

Royal Central School of Speech and Drama, MA Scenography Graduate, London, UKE-mail address: hidayet.tile@gmail.com 
However, spatially speaking, this term becomes a bit problematic, since we start questioning "what kind of goods could a space bear or who the manufacturers would be? Could space be assessed as if it is massproduced and if so, who the buyers are then? In the heart of this paper, the subjects or objects, such as "manufactures, buyers, users, sellers" who played a role in the production of this modern thoroughfare are situated. By proposing the Lefebvrian Triad \& the ANT as a useful combination to analyse space, this paper aims to offer a map to display the producers of the space as if they are devices or tools that contribute to this process while it also discusses what modern means in the early $19^{\text {th }}$-Regency society.

\section{Methodology}

The main methodology of this study is based on Henri Lefebvre (1901- 1991)'s triad; conceived, perceived and lived space (Lefebvre 1991, p.38-39). Lefebvre categorises the phases of production according to the mode of developments, such as dreaming a space and developing it in an abstract way (conceived), concrete development of drawn space (perceived) and experiencing and redeveloping the concrete space (lived). Parsing out the Regent Street into three phases, accordingly, will demonstrate human or non-human elements (buyers, seller, manufactures) who were involved in the production of space. The Actor-Network Theory (ANT) will be used to create a network among those users and manufacturers of Regent Street. Originally, the ANT was developed by Bruno Latour and Michel Callon in the 1980s. It is usually considered as a tool instead of a true theory. According to ANT, agencies could consist of people who are called actors; they might also be nonhumans/non-living things that are actants (Latour 1999, p. 15-25). ANT uses actors and actants as agencies to discuss the urban imaginary in terms of non-material, symbolic and physiological dimensions that construct cities (Rydin, Tate 2016, p. 112-113). Thus ANT will be used as a brush to paint a new form of urban-spatial analysis of Regent street by taking the agencies of the street as different colours.

\section{First Phase of Regent Street: Conceived Space}

Lefebvre describes the conceived space as representations of space. He argues that the "conceptualized space is the space of scientists, planners, urbanists, technocratic subdividers and social engineers, as of a certain type of artist with a scientific bent" (Lefebvre 1991, 38). It is the production of landowners, developers and the architects. Following Lefebvre's theory, De Certeau, coins a new term, the believable space because its function stood for spatial appropriations since it should carry some realistic approaches so that it could be built and most of the time it needed "geometrical, space of visual, panoptical, or theoretical construction" (Certeau 1984, p. 93). As it can be received from both views, conceived space ought to be the earliest phase of Regent Street, where the concept of this development came into being.

According to Lefebvre, all forms, geometry, approaches stands for a political ideology or strategy that triggers a production. (Lefebvre 1991, p.39). Therefore, social, cultural, political reasons behind Regent Street constitute the necessity of the street. People with their strategies, tactics, drawings or things that involved in this phase should be thought as a manufacturer of conceived space.

\subsection{The necessity for Regent Street}

The $19^{\text {th }}$ century streets of London were more than a connection or a road, but they were also the venues for encounters and eventually embodied the link between the King and his people since the streets were the only places where paupers could see and communicate with or even attack to their monarch (figure 1). The Prince Regent knew that he could be vulnerable in those streets and yet he nevertheless was inclined towards luxury, beauty, fashion and indulgence, (Priestley 1969, p. 197) which was seen as a reason behind the creation of the Regent Street. 


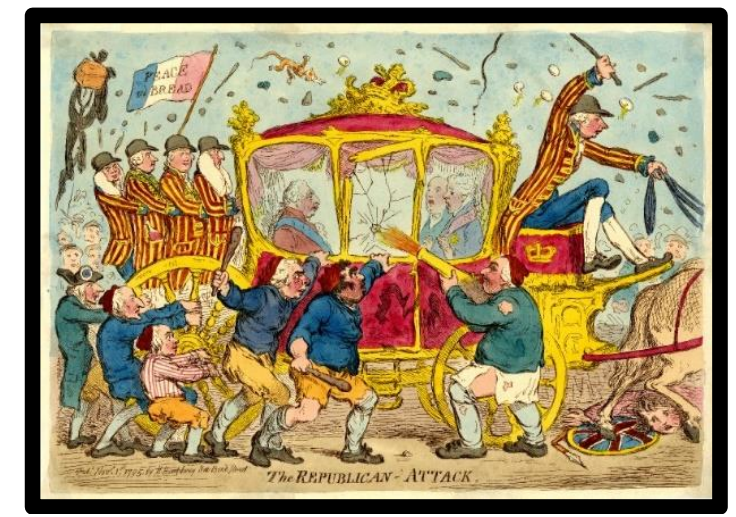

Figure 1: Gillray, J. (1795, 1 November). The Republician Attack. (URL 1)

There were two main reasons for the construction of Regent Street. The first reason was the competition between Napoleon's Paris and Prince Regent's London. Since Great Britain has involved in the Napoleonic war, the war did not take place on the battlefield but also in the form of rivalry between the two cities. Additionally, France was the fashion centre of Europe, and in times of peril, Paris was not welcoming the British people to shop. As a result, Great Britain needed to take care of this problem and come up with its own fashion industry and style. Napoleon commissioned a new Parisian shopping promenade, Rue de Rivoli, as a majestic grand axis in the 1800s, (Ayers 2004, p. 43) while London only had one such elegant shopping promenade on Bond Street and the more modest Oxford Street.

The second reason seemed to be speculative since the Prince Regent personally wanted to get a gentrification project going to accommodate the needs of the upper-class circles. When Prince Regent ordered a new magnificent street, he was living in two different places; first was the Carlton House on the south that was situated on a threshold between the wealthy west London and dirty East London (figure 2). The second location was in Marylebone place on the north, which was one of the Crown estates, yet it was a vast empty area. Many of the members of the upper class, including the Members of Parliament (MPs) live around the Portland Place in the Marylebone district (to the north), while the House of Parliament was adjacent to the Whitehall, which was close to the Prince Regent's mansion, the Carlton House, to the south. The members of the upper class had to use the untidy and winding, meandering roads of the north to get to the Parliament building. This interrupted access was unsatisfactory in the eyes of the Prince Regent. Accordingly, he wanted to get rid of the front the unwanted paupers around the vicinity of his residential quarters in the south, whilst creating a shortcut to his prospective northern palace (Hobhouse 2008, p. 5-11). All these reasons paved the way to the design of Regent Street.

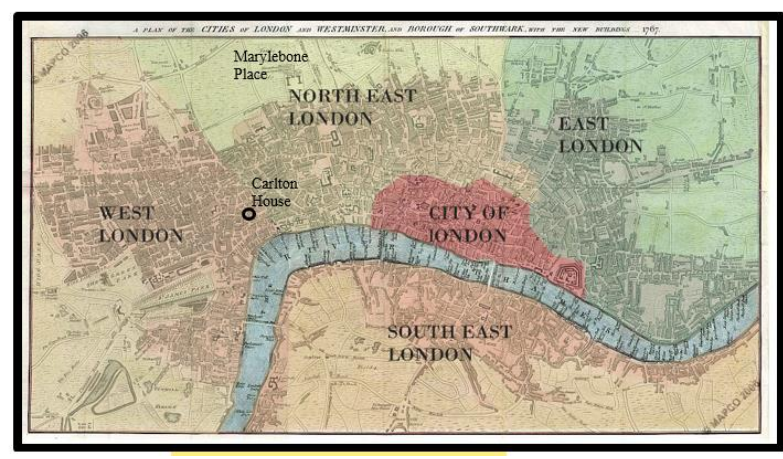

Figure 2: Anonymous (1802) A new Plan of London. (URL 2).

\subsection{Conceptual Design of Regent Street and its tactics}

Regent Street was conceptualised so as to promise a new and pleasant thoroughfare that would create a direct axial link between the north and south of central London while isolating the unwanted lower class bodies in the street (figure 3). To realise his dream, the Prince Regent contracted his architect' John Nash to build a new north-south axis in 1811 . Nash designed a shopping thoroughfare that made the Prince Regent reportedly have said: "It will quite eclipse Napoleon" (Armytage 1968 p. 39).

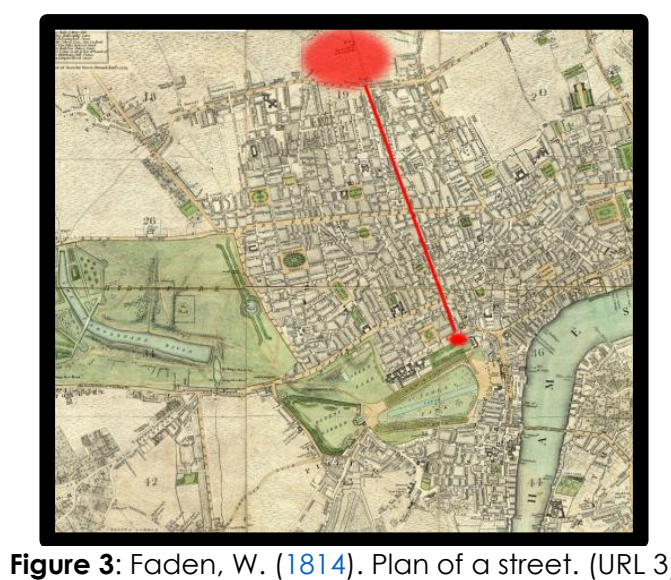
${ }^{1}$ Since Prince was the Patron of Nash for his Brighton Pavilion, he
liked Nash's monumental and neoclassic style. 
In his first proposal, Nash drew two axial lines between Marylebone and the Carlton House. He decided to follow Portland Place's (the widest street in London) track to create an axial line between Marylebone Place to the Carlton House and proposed a Royal Park for the vast area at Marylebone Place (figure 4). The new street would take people directly to the south without passing through the dirty and untidy lives of the lower classes. As it also has drawn sharp borders for those who arrived from the East, it visually and physically tried to interrupt the movement from the slums of east London. However, this plan was rejected by many people, including the landowners and building leasers because many of the buildings would have to be demolished, leaving many homeless.

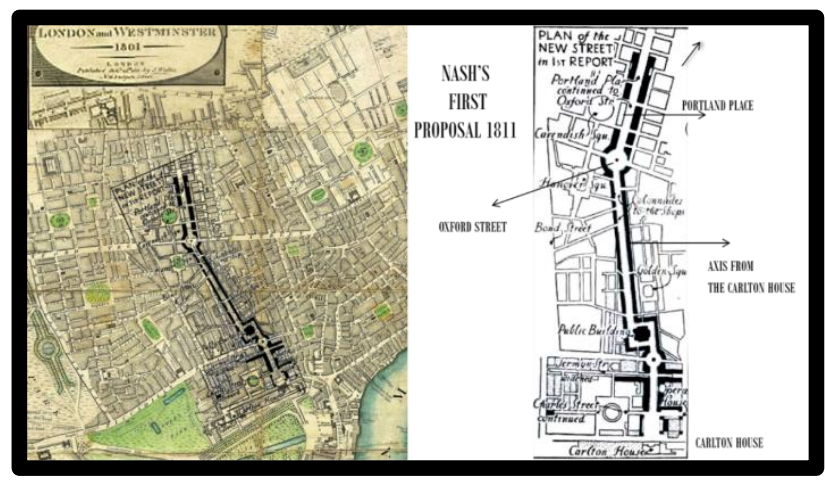

Figure 4: Nash followed the line of the Portland Place in between the Carlton House repaint by the author.

Being rejected on the first proposal, Nash presented the second proposal in which he again used the guidelines with the Portland Place in the north but the southern axis covered and swept away Swallow Street where many of the buildings belonged to the Crown (figure 5), so compulsory purchase orders were not necessary. The redevelopment would increase the value of the lands owned by the Crown so the monarch could gain more financially from this modern and fashionable trade centre (Hobhouse 2008, p. 4-9)
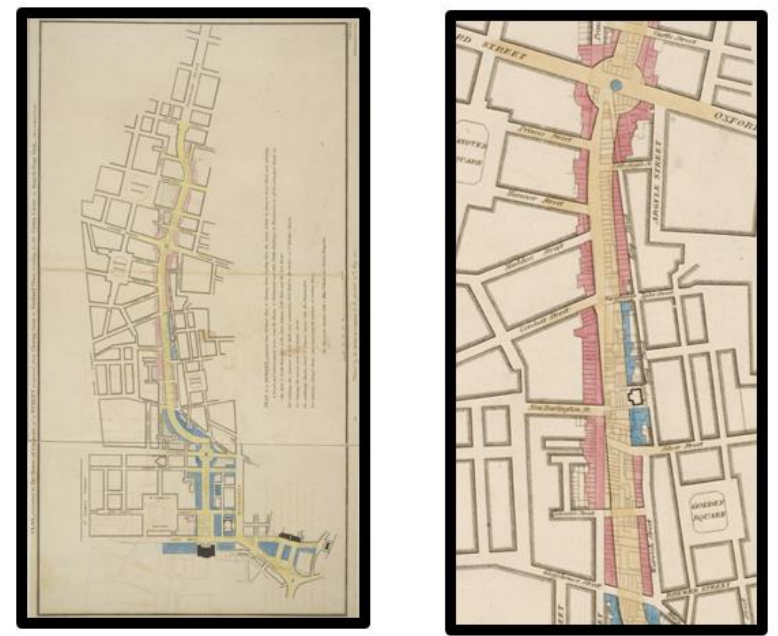

Figure 5: Faden, W (1814) Plan of a street. (URL 3)

The concept was still the same, creating a straight and the shortest connection between the North and South London. However, the orientation of the street needed to be altered as Nash changed the alignment of the street where Swallow Street, which was believed to be an "ugly and grimy old thoroughfare." stood in the South. It was situated within the Crown Estate land in the West where upperclass residents lived close by. Nash apparently had in mind a project which would satisfy his patron, the Prince Regent, and his upper-class circle of friends with the creation of a fashionable street. He wanted to create a "boundary and complete separation between the streets and squares occupied by the Nobility and Gentry, and the narrow streets and meaner Houses occupied by mechanics and the trading part of the community" (The Universal Magazine 1747, p. 16). The new street would sharply curtail the communication with the East side of the street; working and lower classes and their traffic would be avoided (figure 6).

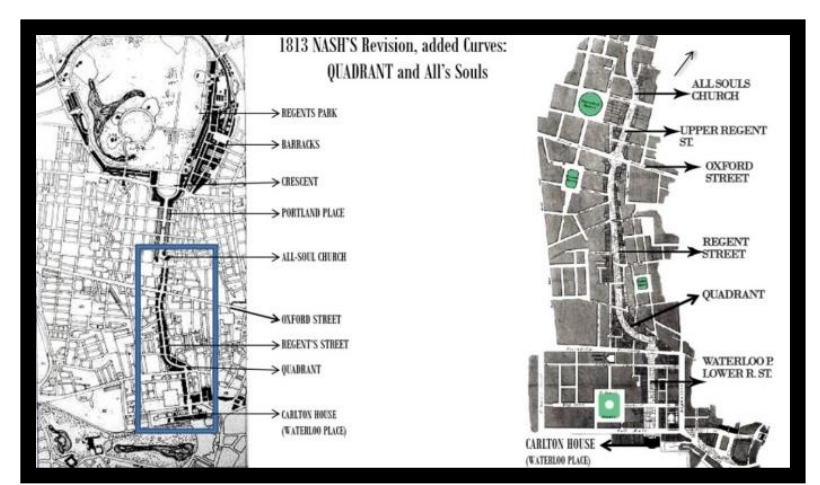

Figure 6: Nash's second proposal in 1818 and the joints created by the author 
The new body of the street was called Regent Street that was named after its patron. Regent Street comprised of five main parts from North to South that were Pall Mall (Carlton House), Lower Regent Street, the Quadrant, Upper Regent Street, and Park Crescent with Portland Place. Between these five parts, Nash had drawn the curvy joints to create a fluid street eliminating any zigzags or dark, hidden corners.

\subsubsection{Segments of the Regent Street}

Nash was not the only decision-maker in this huge redevelopment plan. The project also involved various architects of the period, namely John Soane, Burton and R.C. Cockerel along with different investors (Richardson 2001, p. 42). Construction literally began in front of Carlton House (1818), and it has always been the Southern terminal of the street that was called Waterloo Place an Lower Regent Street (figure 7).

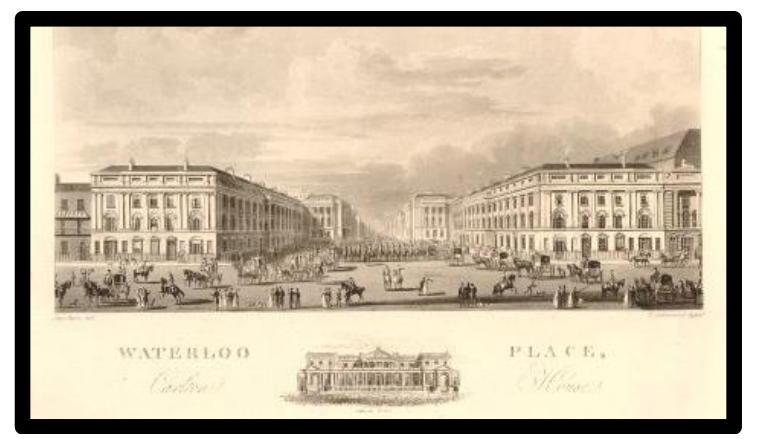

Figure 7: Sutherland T. (1817). Carlton House. (URL 4)

Here was unlikely to have been a residential area for families since there were hotels where foreigners came to stay; housing, clubs, and chambers mostly served the Westerners and the upper class. However, there were also warehouses, opticians and carpenters and hosiers, where lower-class and middle-class people were able to work.

Compared to Waterloo Place, Regent Street \& Quadrant was part of the commerce and shopping of the metropolis (figure 8). The Quadrant, as a singular and unique place, provided a curvilinear connection between Regent Street and Carlton House. The shops were on the ground floor and the bachelor apartments on the upper levels. That is, mixeduse buildings where a range of shops for food and fashion from tailors to biscuit and bread baker could be found (Tallis\& Jackson 2002).

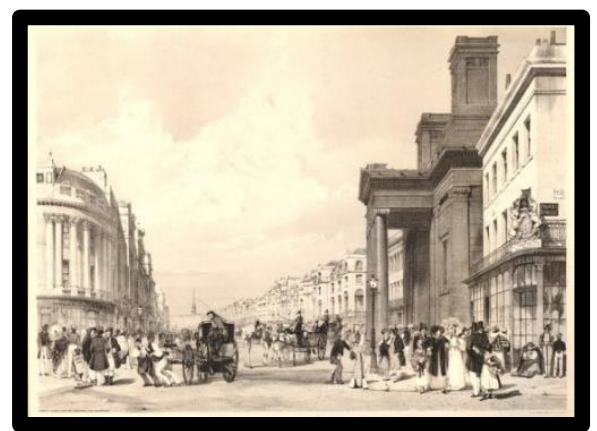

Figure 8: Boys, TS (1842) Regent Street, Quadrant. (URL 5)

Portland Place or Upper Regent Street was designed with private residential houses (especially for Members of Parliament), All Souls Church, as well as shops. Also, group of surgeons (No: 311), a Polytechnic Institution ${ }^{2}$ (No 309) and some manufacturers were located among the houses of here.

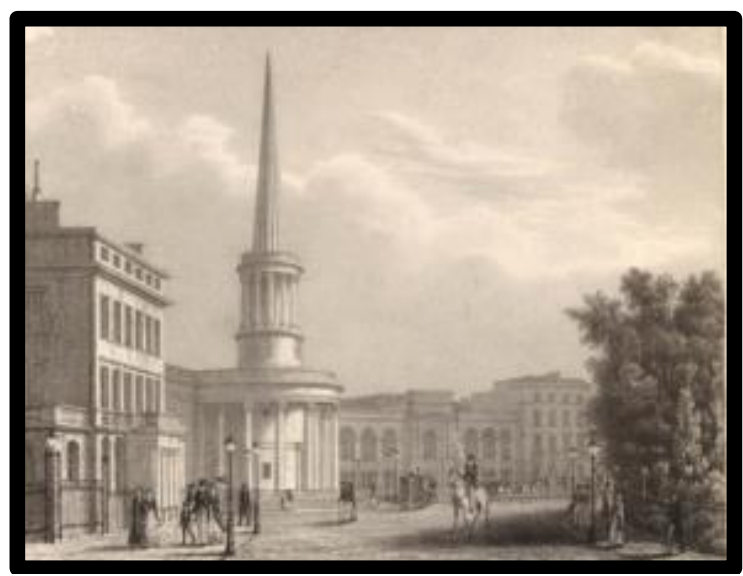

Figure 9: Heath, C (1825) All Souls Church. (URL 6)

While having a direct link between North and East axis, Regent Street was dreamed like a complex where one can find almost anything from health to education. In this initial phase, the production of Regent Street was more mental and abstract because it was based on various desires and concepts of the Prince and the architects who were in charge of the projects. Maps, plans, drawing and diagrams are necessary sources to survey the conceived space of Regent-street as it is also known as a representation of space where an idea, ideologies, political or architectural visions are embedded in and visually represented (Lefebvre 1991, p. 9). Network 1, as seen in Figure 10, stands for this relationship

\footnotetext{
${ }^{2}$ The Polytechnic Institution at 309 Regent Street (1838) was created in order to demonstrate new technologies and inventions, played a significant role in the popularisation of science. It is now University of Westminster. university/our-heritage
} 
amongst the elements that contributed to the development of conceived space.

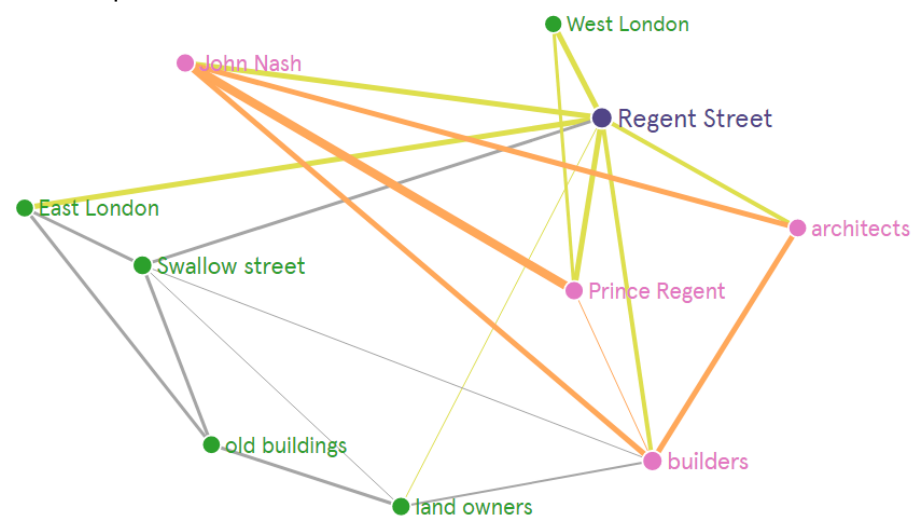

Network 1: The relationship between the actors / actants in conceived space, created by the Author.

While the street was shaped by its manufacturers like Prince Regent, John Nash, other builders and architects, it also produced its own buyers (visitors or occupants). These occupants would have a crucial role in the production of the perceived and the lived spaces since these two productions could only be possible through the actors and actants of Regent Street.

\section{Second Phase: Perceived Space}

Lefebvre says that: "...spatial practice embodies a close association within perceived space, between daily reality (routine) and urban reality (the routes and networks which link up the places) set aside for work, 'private' life and leisure" (Lefebvre 1991, p. 38). Consequently, the perceived space is analysing the users or manufacturers; it is possible through observing the daily experiences, urban actors or practitioners in the urban realm.

Although Nash dedicated the street to nobility and gentry, there were various buildings in Regent Street designated for different functions including insurance offices, shops, and private apartments. Besides the mobility and gentry, there were many lower and working-class people ready to serve upperclass members in these shops and apartments. People from different classes were the actors (occupants) of the street to provide continuation of the action, and they created a texture with various activities, memories or experiences regarding their background.

\subsection{Agencies of the Regent Street:}

Actors and actants are essential elements to understand perceived and lived space because such space will be analysed by the senses or perceptions of the people, including touch, taste, sound, smell and sight.

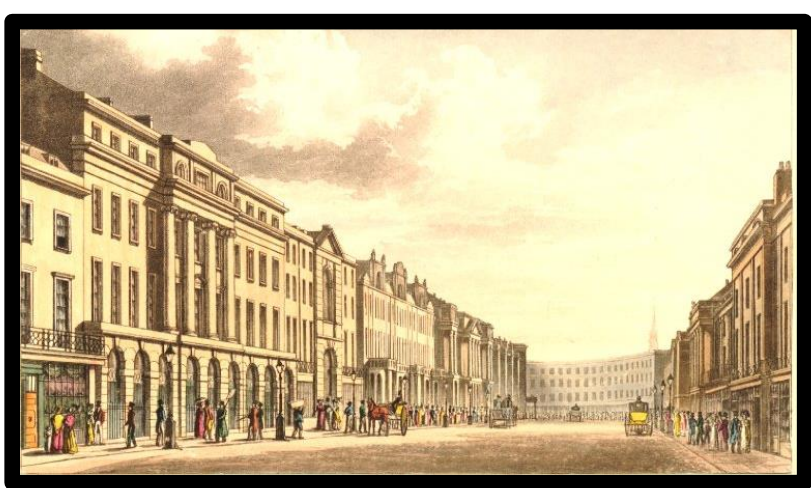

Figure 10: Ackermann (1822) View in Regent Street, Piccadilly. (URL 7)

The perception of space in the $19^{\text {th }}$ centuryRegency London would only be received through visual or verbal media such as architectural drawings, satirical cartoons, diaries, novels and some architectural reports. Figure 10 represents the actors, fashionable women wearing softly coloured dresses, and men wearing dark-coloured suits and hats and both sexes shopping, strolling along, working or just passing through the street. The actants are the carriages with their horses, gas lamps with metal frames, signs in the shop windows, and whitish buildings with their neoclassical styles. The ANT believes that society is an assemblage in which the relationship between elements, rather than the elements themselves, are the key focus (Rydin \& Tate 2016, p. 4). The visual images display 3-dimensional spatial practices in the street along with visible actors and actants, yet it hides many codes and invisible agencies that are also embedded in the urban structure. Nonetheless, agencies of Regency 
in drawings or illustrations usually concern the upper classes since many of the literate people were among rich (like ladies and gentlemen), or they were the only customers to buy visual sources like paintings or cartoons. Yet, still, they are usefull elements to shed light into invible agencies and make an assumption on perceptual space of Regent Street out of their intrepration.

\subsubsection{Ladies of the Regent Street:}

And the ladies are pleased their sweet face to show Off to all when Regent Street 'shopping' they go, And often I marvel how much they all buy-Not one day in the week but 'a shopping' they hie! This Regent Street quite like Rue de la Paix And les elegants here, too, spend most of the day, And lounging about- for what else should they do? (Best 1829, p. 102).

As Best has indicated the body of female visitors in his poem, Regent Street cannot be imagined without women and especially wealthy female bodies who were most likely to buy items to represent the grace via their fashionable bodies. To analyse the perceptions out of women as actors; the ANT scrutinises actors and actants as a system of symbols to discover perceptions behind the scene to map all perceptions that are linked to an agency.

For example, the figure 10 shows the Regency ladies wearing fashionable Neoclassical style dress in front of the neoclassical buildings that cannot be coincidence according to ANT since buildings and ladies fashion shared the same political, historical and cultural perceptions. The French Revolution and conflicts between England and France triggered the development and concept of liberty, and the atmosphere in Europe transformed the way of thinking about freedom, self-consciousness and power (Clark, 2013, 120-268). Freedom in art, architecture, and fashion was seen particularly in England and France which moved away from the extravagant style of Rococo to prove and show that they were more conscious and earnest about the world (Moores 2015, p. 73) as they believed that their style ought to express their personality. Subsequently, they returned to the serious and sensible philosophy of Greek and Rome by means of a Neoclassical revival (Kemp 2000, p.265). Thanks to the grand tours travelling to ancient cities like Rome, Athens and Cairo, travellers (especially the architects) began to learn about the values and aesthetics of the classical world, their governing systems and lifestyles. The Neoclassical style impacted on art, architecture and fashion (figure 11) in a similar way (Palmer 2019, p.186). The British played a very different role in the quick adaptation of the Neoclassical Style. Between 1801 and 1805, Lord Elgin, the British ambassador to the Ottoman Empire, depatriated about half of the remaining sculptures from the fallen ruins of the Acropolis, Athens with the permission of the Ottoman authorities. As Lord Elgin was passionate about ancient Greek art, he transported those marbles to Britain. From 1807 onwards, he exhibited them in his temporary museum in London for a number of years. The Elgin Marbles assisted architects who wanted to observe the antique details first hand. Georgian and Regency architects who went abroad or observed the Elgin Marbles created their own architectural style by being aware of their stylistic freedom. Moreover, the idea of liberty could be seen in different aspects in the architecture of Regent Street, such as providing a welcoming space for both sexes and all classes or producing a space which was designed in the spirit of architectural freedom, that is completed by free and sometimes eclectic facades of the buildings (figure 11).
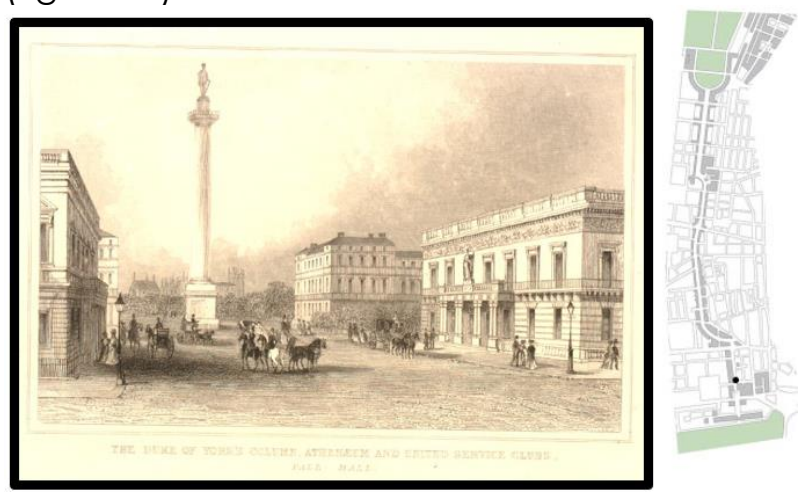

Figure 11: Anonymous (1828). Waterloo Place. (URL 8)

Sir John Summerson points out that three concepts of revivals characterise the 18th and 19th century periods (Summerson 1958, p. 92 ). Summerson says that:

"First, the concept of art through archaeology, that is, of the enrichment of the present by a persistent inquiry into the nature of past las opposed to the acceptance of the traditional theory of antiquity). Second a wider 
concept of eclecticism, of the power to choose between styles or to combine elements from different styles. Third by the analogy, the concept of a modern style, a style uniquely characteristic of the present" (Summerson 1953, p. 17).

Eclecticism can be witnessed in parallel in both the faces of the ladies and the architecture around them. Coordinating different designers and builders, Nash was the creator of this freedom and opportunism in the street, and these concepts can even be discerned in the eclectic and free facades of the buildings (figure 11-12).
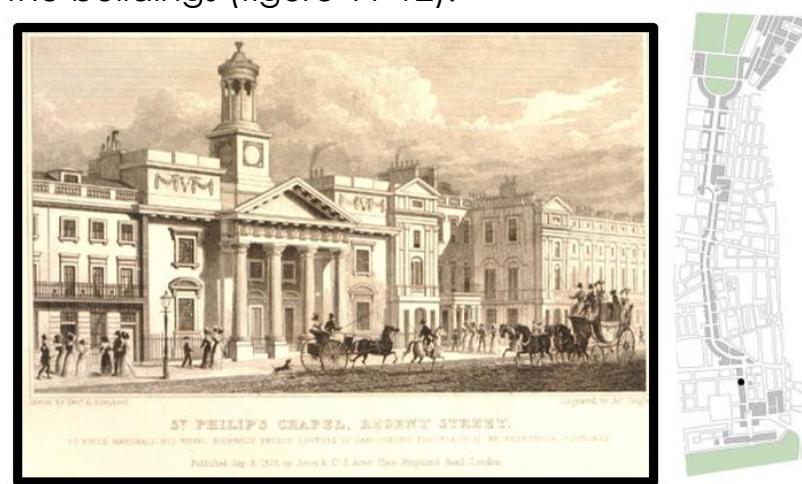

Figure 12: Tingle, J (1827) St Philip's Chapel.( URL 9)

The presence of these stylish ladies and the neoclassical buildings in Regent Street are the signifier of various notions, (perceptions) such as ancient Greece with the Elgin Marbles, the Grand Tour, beauty and grace. Furthermore, these signifiers were linked to liberty and personal freedom, class differentiation, war with France, the Industrial Revolution since they were the actants, yet they were not explicitly represented howered they all liked to each other as it can be seen on Network 2.

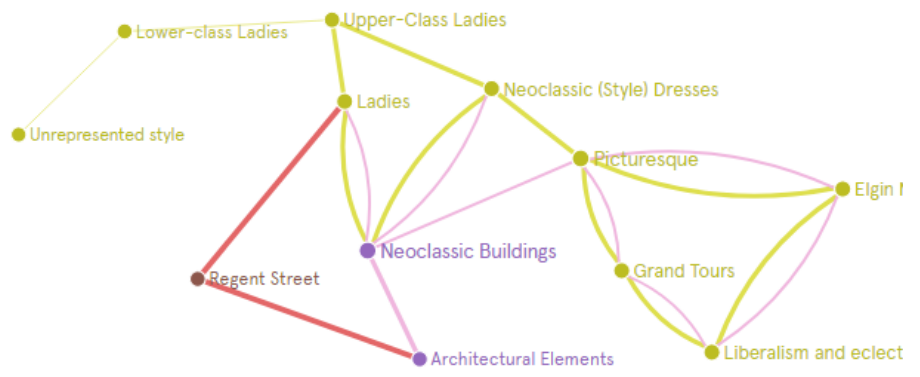

Network 2: Network among female bodies and urban/ architectural elements created by the authour

\subsubsection{Gentlemen of the Regent Street}

Just as women's bodies had benefitted from the democratic ideals of the Enlightenment, men too soon after found the freedom to express their clothing tastes in a simpler and more subtle style. They used mainly blue, black-buff, white, dark colour coats, polished boots and elaborately knotted cravats. Regency men were the patrons of the Regency world as many of them were politicians who governed the country or generals and admirals who led the armed forces at war. By being aware of the conflicts and uncanny situation of the world, Regency patrons combined a certain seriousness of the uniform dress with machinery and politics. Thus the modern English men display a dark, sharp and modern silhovette as if it is an engine or a machine, and Beau Brummel was the creator of this style (figure 13).

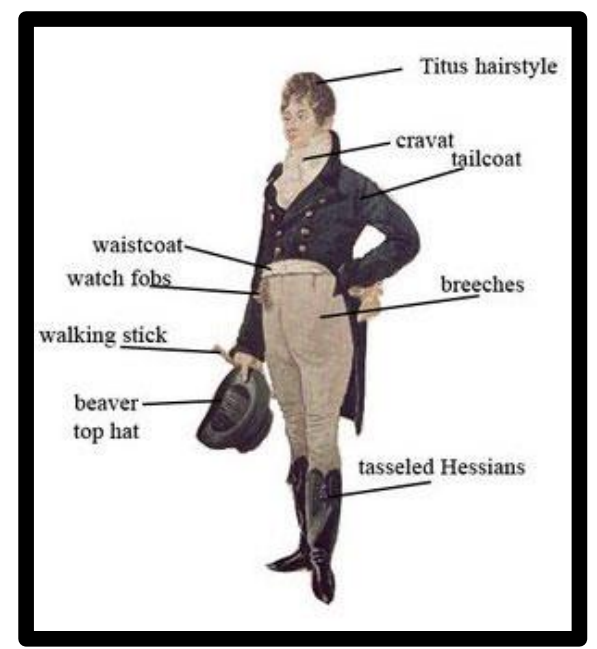

Figure 13: Locke M. E. (2015) Modern Englishman Style of Brummel (URL 10)

A reflection of this modern and mechanistic look of men can be seen in the substantial metal frames of the windows, and the metal works in the balconies on the domes to the top of the building (Figure 14). While large and exclusive windows provided bright shops and interiors during the day, the street could remain bright at night as well at night as the street (gas) lamps that were installed by The Prince Regent for the first time (1818) to illuminate the area in front of his door at the beginning part of Lower Regent Street. Willis shared his feelings on the gas lamps as:

"..and so think, apparent the multitudes of people, who stroll up and down the clean and broad London sidewalk, gazing in at the gorgeous succession of shop windows, and by the day bright glare of the 
illumination exchanging nods and smiles- the street, indeed, becoming gradually a fashionable evening promenade, as cheap as it is amusing and delightful" (Willis, 1854, p. 538).

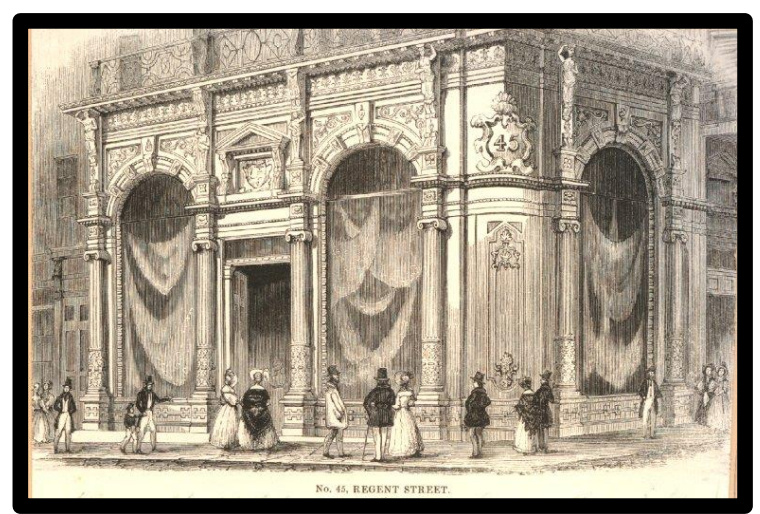

Figure 14: Anonymous (1840-1850), No. 45 Regent Street. (URL 11)

Regent Street bodies followed the same configuration as modern Englishmen, and it turned into a practical machine that contained mixed-use buildings. Considering practicality and the functionality of the street, Nash also proposed a sewer system to be utilised by all classes in the street since London was threatened by the epidemics due to the poor hygienic conditions of the country (Figure 15).

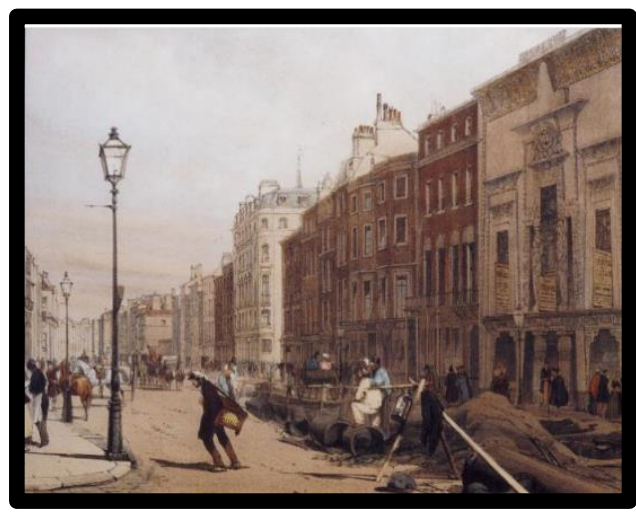

Figure 15: Webb, R. (2001) Installing the sewer system in between the Quadrant

Moreover, there were the street sweepers to clean Regent Street that was covered with wood first and then replaced by a granite stone pavement which was believed to be safe and more efficient at absorbing the filth (Newton 1839, p.338). Regent Street became a practical and functional by generating a perception of modern and practical living space.

As it is seen on Network 3 things that do not seem related to each other are actually connected to one another to create perceptions, memories in space and ANT demonstrates a network that stands for perception generator of the street.

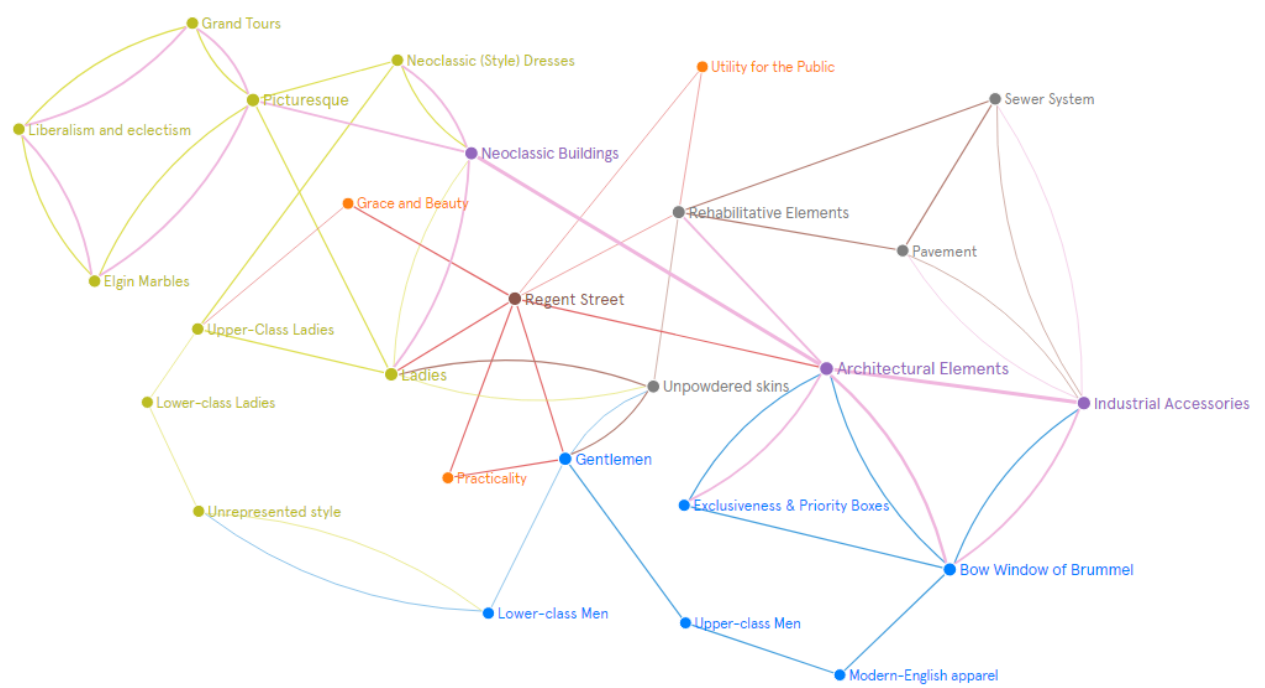

Network 3: Network among the agencies of the Street.

\section{Lived Space and Social Production of Regent Street}

When Soja describes the spatiality, historicity and sociality of the space, he uses the notion of a third space that he coined himself (Soja, 1996). He asserted that "I described the critical method used by Lefebvre and
Foucault 3 as "thirding", a deconstruction of prevailing binary logic and the creation of a third, an alternative, a significantly different

\footnotetext{
${ }^{3}$ Soja refers Foucault's Heterotopia in Of Other Spaces: Utopias and Heterotopias. http://web.mit.edu/allanmc/www/foucault1.pdf
} 
logic of perspective" 4 . More explicitly, the notion "third" concerns the fluidity of spaces with the constructing and reconstructing of identity, and the space where identity is not fixed and as such is the feature of any kind of spatial existence 5 . De Certeau used the term dream spaces to define where a new and carved version of the old space merged and made that space an infant. Both dream and third spaces correspond to the Lefebvrian lived space and he explains it through perceived space (representational space) because lived space (social production) was an extension of the spatial practice (perceived space) through the course of time. As he points out,

"Representational space is alive: it speaks. It has a valid kernel or centre: ego, bedroom, dwelling, and house or: square, church, graveyard. It embraces the loci of passion, of action and living situation and thus immediately implies time" (Lefebvre 1991, p. 42).

In the context of Regent Street, from 1811 to 1848, one can observe a new fluid or third/alternative space. It was the year 1818 when the street was born, and then it was in 1848 when the first deconstruction was started by the removal of the arcades in Quadrant. Nash himself designed this junction as a barrier to prevent the entry of the people who came from the dirty streets of Soho and provided an exclusive atmosphere with its great shelter for West Londoners at the same time. Doric shaped columns created a dramatic atmosphere with an exclusive shelter that protected people from bad weather (figure 16).

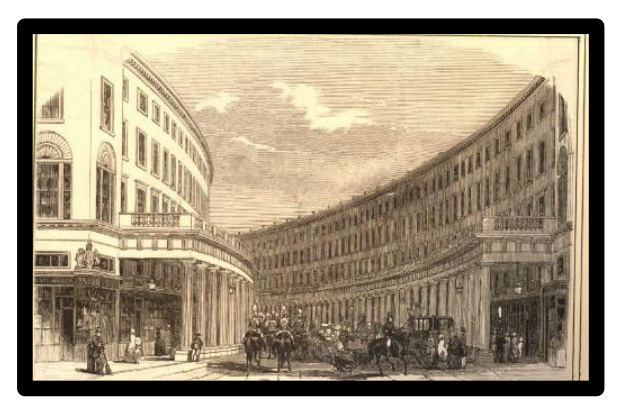

Figure 16: Anonymous (1848), The Quadrant. (URL 12).

${ }^{4}$ https://www.tandfonline.com/doi/abs/10.1080/1600910X.2002.96 72816?journalCode=rdis20

${ }^{5}$ http://shodhganga.inflibnet.ac.in/bitstream/10603/184562/14/9 c hapter3.pdf
However, by the 1840s, this protective shelter had begun protecting the bodies of East End prostitutes. Since the street was dedicated to the West End upper-classes, the bodies of the Eastern poor were not welcome and especially the women of this particular trade. The Parliamentary Papers of 1846 demonstrated that, "congregation of the low and vicious has so far injured the reputation of the Quadrant, and obtained for it an unfortunate notoriety, that we have good reason to believe many ladies are deterred from visiting it, to the serious injury of our trade", referring to the vice and prostitution taking place in the shelter of the Quadrant (Parliamentary Papers 1846, p. 511). Hence, it was not a safe place for respectable, decent women. Many letters of complaint and criticisms were answered by the Commissioners of Her Majesty's Woods with an agreement for the demolition and deconstruction of the Quadrant in 1848 (figure 17).

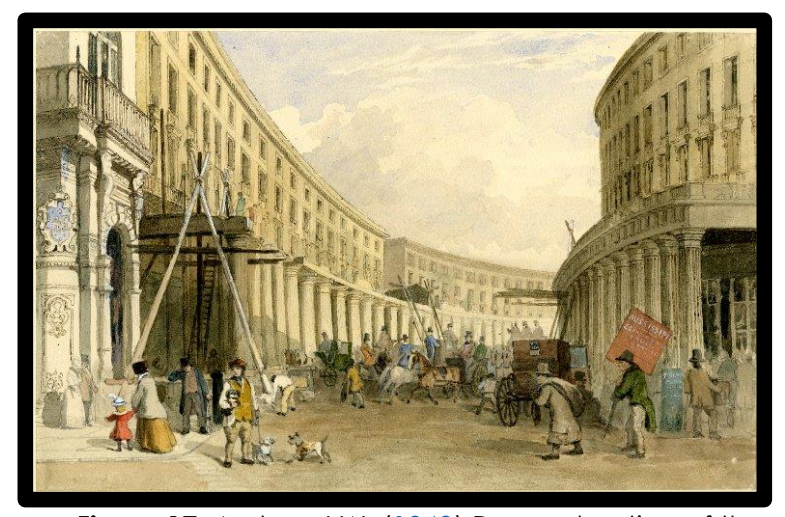

Figure 17: Archer, J.W. (1848) Deconstruction of the Quadrant. (URL 13).

This removal was not appreciated by those who used to enjoy the shelter it provided on a rainy day. The Punch magazine criticised the roofless Quadrant again, and it published a sketch to describe a "movable colonnade" consisted of the people and their mobile umbrellas. Figure 18 shows the individuals who used to walk under the colonnade paying homage to the memory of the arcades and only walked under where the invisible colonnade had once stood (Punch 1848; vol: 12-15, 270). 


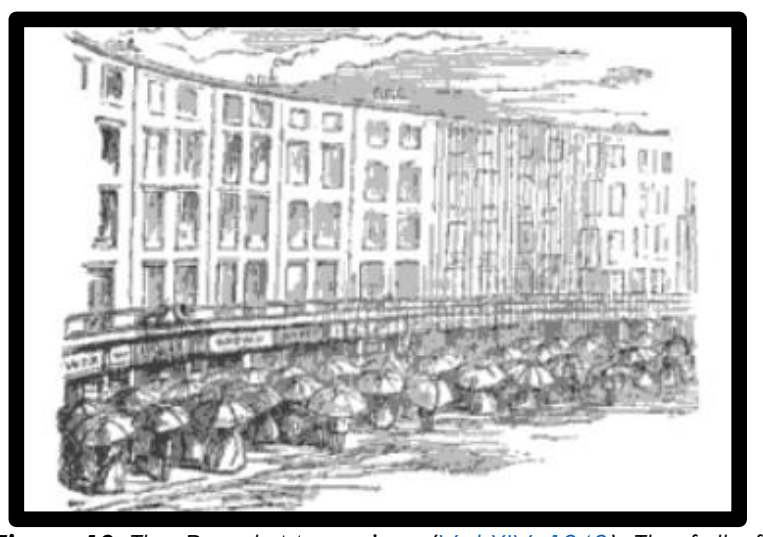

Figure 18: The Punch Magazine. (VoI XIV, 1848). The fall of the Quadrant.

As can be seen in Figure 18, society still keeps the memory of shelter of the quadrant, and they produce their own route on a rainy day. The fact behind the social reproduction is based on practising the built environment. Practitioners are the daily actors that are built by the spirit of the age or not since society is the real owner and producer of lived space.

\section{Conclusion}

Lefebvre states that every society produces its own space, it is based upon what is owned, what is needed, and what is embedded in its culture. I believe that society does not produce only goods but also their bodies and identities parallel to their zeitgeist. In this research, I have tried to demonstrate that everything in society specifically in Regency is an agency that is connected to another, is metaphorically a piece of a machine that manufacture/produce goods or here Regent Street. Accordingly, I have categorised the production into three phases of Lefebvre, and for each phase, I have drawn a network system to show the relation and interaction among them.

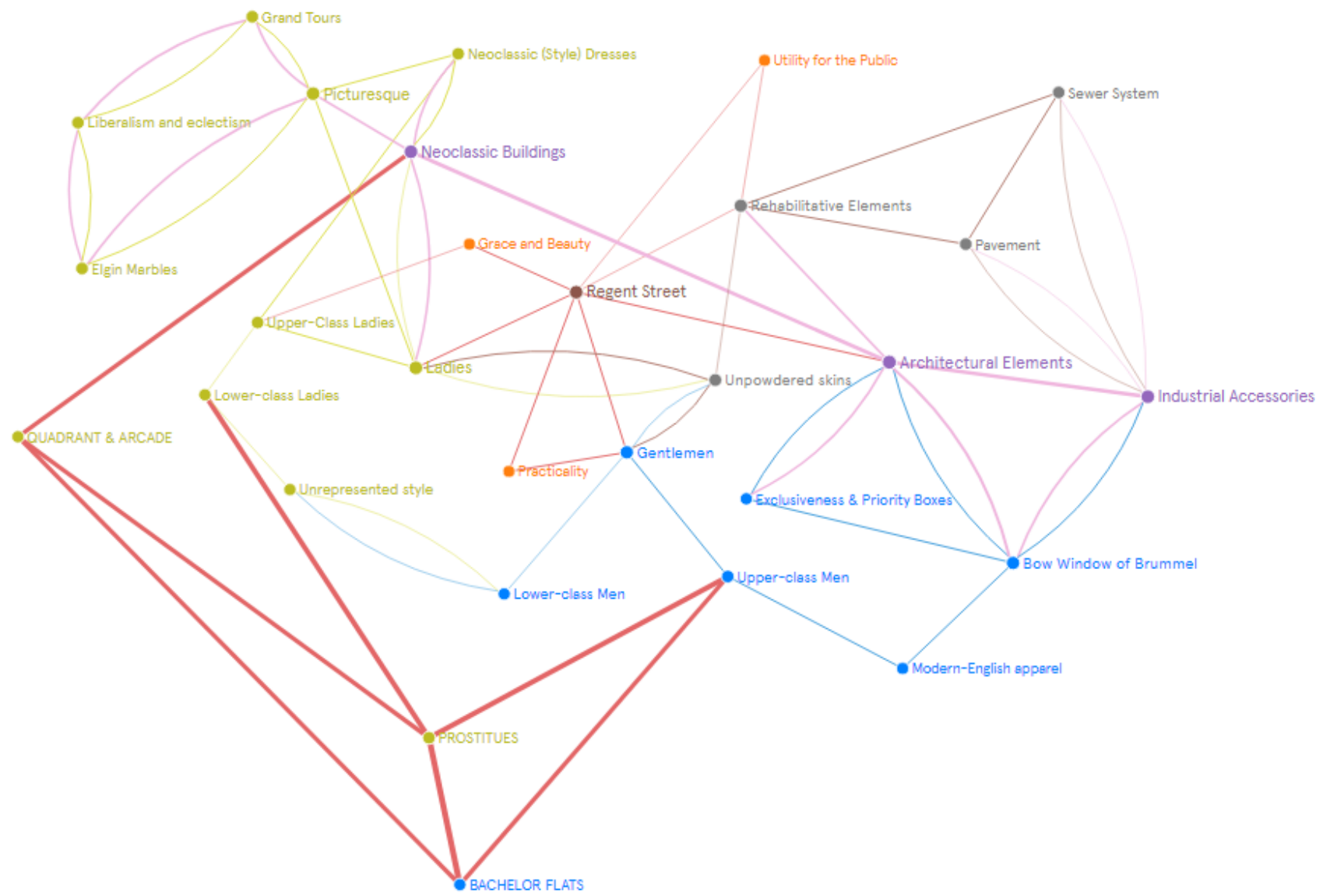

Network 4: The relationships between actors and actants.

It can be seen in network 4 that each elements of society, either visibly or invisible, directly or indirectly, are linked to each other. I believe that seeing this interaction in this network is essential to call Regency as a modern society. The introduction in Bruno Latour's (1993) "We Have Never Been Modern" has convincingly argued that we are not even close becoming modern since we 
do not see the things with what they are connected to. This simply means that the basis of modernity is to see beyond the agencies with their invisible agencies that are connected to. Sennett described the modern Western cities as places where human bodies were aware of one another's flesh (Sennett, 1994). It is Regency where this awareness has started since the different classes start seeing and being aware of each other's political body that was linked to visibility in the social realm because mobility and performances in the cities were not only to see but also to be seen by others since visibility was a condition to prove self-presence and even dependence (Arendt, 1969).

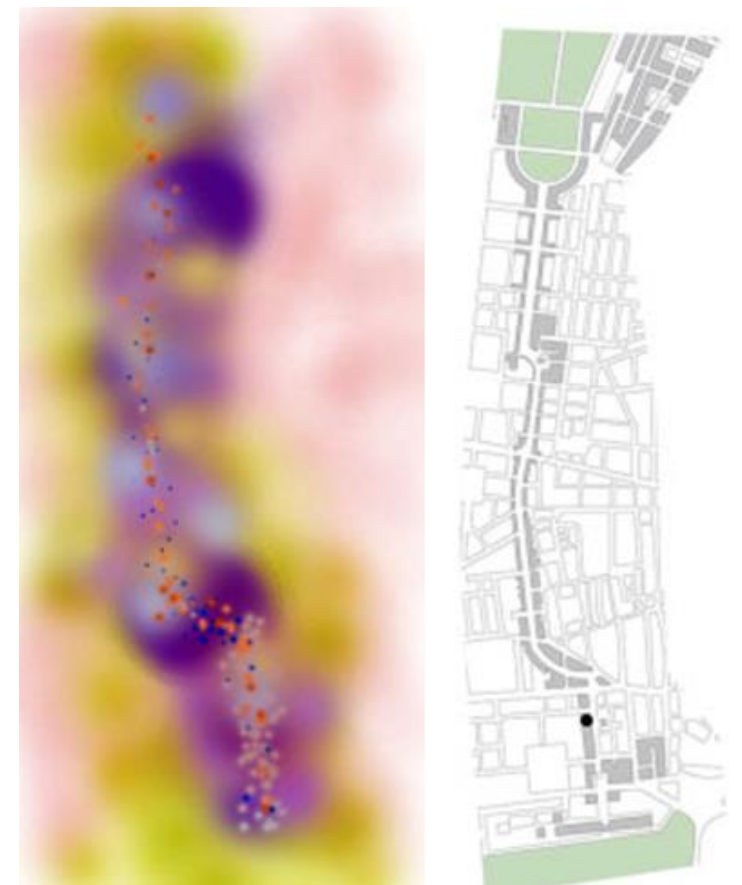

Figure 19: Proposing an original Paint of Modern Life (left) in Regent Street painted by the author.

Last but not least, by using data on the network system that is based on spatial triad, I would like to propose an original illustration of Regent Street (1818-48) that is inspired from the "Painter of Modern Life" where each colour stands (used the colours in-network; yellowish-orangeish/ladies/shops,

blues/gentlemen/machinery,

greyish/practicality/hygiene,

purplish/neoclassicism/eclectism) for an agency (the same colour coded in the network) to represent the layers of modern societies. All those colours stand for themselves and interact or create new colours and a blurred harmony rather than a sharp distinction by touching the skin of each other. This new colour is like touching each other's skins and triggering a new type of production. It is obvious that the production of space is a term that stands for a process and progress rather than an end or result since each production is destruction that follows one Another.

\section{Acknowledgment}

This research did not receive any specific grant from funding agencies in the public, neither commercial, nor not from profit sectors.

\section{Conflict of interests}

The Author declares no conflict of interests.

\section{References:}

Arendt,

$\mathrm{H}$.

(1969). The

human condition. (Walgreen Foundation Lecture Series). University of Chicago. Retrieved From:

http://sduk.us/afterwork/arendt_the h uman condition.pdf

Armytage, W. (1968). The French influence on English education. (Students library of education). Retrieved From:

https://books.google.com.tr/books/ab out/French_Influence_on_English_Educ ation.htmle id =4tdakUlyf4C\&redir_esc $=y$

Ayers, A. (2004). The architecture of Paris / Andrew Ayers. Stuttgart; London: Edition Axel Menges. Retrieved From: https://books.google.com.tr/books?id $=$ EN5PAAAAMAAJ\&redir_esc $=y$

Best, J. R. (1829). Cuma, the Warrior-Bard of Erin, and other poems. (AEneas in the Infernal Regions: From the Italian of Canon Andrea de Jorio.) With maps. London: British Library, Historical Print Editions.

Clark, P. (2013). The Oxford handbook of cities in world history / edited by Peter Clark. (Oxford handbooks in history). Oxford: Oxford University Press.

Certeau, M. (1984). The practice of everyday life. University of California Press. Retrieved From: 
https://monoskop.org/images/2/2a/De CCerteau Michel The Practice_of_Eve ryday Life.pdf

Hobhouse, H. (2008). A history of Regent Street. London: Macdonald and Jane's in association with Queen Anne Press. Retrieved From:

https://books.google.com.tr/books/ab out/A_History of Regent_Street.html? i $\mathrm{d}=\mathrm{aPELAQAAMAAJ \& redir}$ esc $=\mathrm{y}$

Kemp, M., (2000). The Oxford History of Western Art, UK: Oxford University Press. Retrieved From:

https://books.google.com.tr/books?id $=95 \mathrm{~J}-$

ppmZmt8C\&printsec $=$ frontcover\& $d q=K$ empThe+Oxford+History+of+Western+ Art,+Oxford+University+Press\&hl=tr\&sa $=$ X\&ved=0ahUKEwjO3Y6s8bjjAhUQp4sKH $\underline{Y L s B 1 A Q 6 A E I K Z A A \# v=o n e p a g e \& q \& f=f}$ $\underline{\text { alse }}$

Latour, B. (1993). We have never been modern / Bruno Latour; translated by Catherine Porter.New York; London: Harvester Wheatsheaf. Retrieved From: https://books.google.com.tr/books?hl= tr\&lr=\&id=xbnK8NzMsm4C\&oi=fnd\&pg =PR9\&dq=we+have+never+been+mo dern\&ots $=$ TjOdjs838\&sig $=1 \mathrm{bL}-\mathrm{cc} 3 \mathrm{~N}-$ OFsly0pzQ-

GfFCacPY\&redir_esc=y\#v=onepage\& q=we\%20have\%20never\%20been\%20 modern\&f=false

Latour, B. (1999). On Recalling Ant. The Sociological Review, 47(1), 1525. https://doi.org/10.1111/1.1467954X.1999.tb03480.x

Lefebvre, H. (1991). The production of space / Henri Lefebvre; translated by Donald Nicholson-Smith. Oxford: Basil Blackwell. Retrieved From:

https://monoskop.org/images/7/75/Lef ebvre_Henri The Production of Space .pdf

Moores, R. (2015). Representations of France in English Satirical Prints 1740-1832. DOI: $10.1057 / 9781137380142$

Newton, W. (1839). Newton, W. The London journal of arts and sciences, and repertory of patent inventions. London: Sherwood, Gilbert, and Piper. Retrieved From: https://archive.org/details/londonjourn alar13newtgoog/page/n7

Palmer, A. (2019). Historical Dictionary of Romantic Art and Architecture / Allison Lee Palmer. (2nd ed.). Retrieved From: https://books.google.com.tr/books/ab out/Historical Dictionary of Neoclassic al_Ar.htmleid=dUNJICURJL8C\&redir_es $\mathrm{c}=\mathrm{y}$

Parliamentary Papers. (1846). Appendix to the Reports of the Select Committee of House of Commons on Public Petititons, Great Britain. Retrieved From:

https://libguides.bodleian.ox.ac.uk/par liament/1800-2000

Priestley, J., \& George IV, King of Great Britain. (1969). The prince of pleasure [i.e. George IV] and his regency, 181120. London: Heinemann. Retrieved From:

https://archive.org/details/princeofple asure0000prie

Punch Magazine, 1848, vol: 12-15. London: Punch Office. Retrieved From: https://sites.google.com/site/punchvol umes/

Rydin, Y., \& Tate, Laura Ellen, editor. (2016). Actor networks of planning: Exploring the influence of actor network theory / edited by Yvonne Rydin and Laura Tate. Retrieved From: https://books.google.com.tr/books?id =fomPCWAAQBAJ\&printsec=frontcove $\underline{r \& h l=t r \& s o u r c e=g b s \_V i e w A P I \& r e d i r \_e s}$ $\mathrm{c}=\mathrm{y} \# \mathrm{v}=$ onepage $\& \mathrm{q} \& \mathrm{f}=$ false

Richardson, A. (2001). Monumental classic architecture in Great Britain and Ireland / Albert E. Richardson; introductory notes by $H$. Stafford Bryant, Jr. (New ed.). Mineola, NY: Dover.

Sennett, R. (1994). Flesh and stone: The body and the city in western civilization / 
Richard Sennett.New York; London: W. W. Norton. Retrieved From:

https://www.academia.edu/36755938 SSennett Richard FLESH AND STONE

Soja, E. (1996). Thirdspace: Journeys to Los Angeles and other real-and-imagined places / Edward W. Soja. Cambridge, Mass.; Oxford: Blackwell. Retrieved From:

https://kupdf.net/download/edwardw-soja-thirdspace-journeys-to-losangeles-and-other-realandimaginedplaces-

lpdf_5a99624ee2b6f5d6013a0912_pdf

Summerson, J. (1953). Architecture in Britain, 1530 to 1830. ([Pelican History of Art.]). Retrieved From:

https://books.google.com.tr/books/ab out/Architecture_in_Britain_1530_to_18 30.htmleid=o7FoFUkbJ_gC\&redir_esc=y

Tallis, J., Jackson, Peter, \& London Topographical Society. (2002). John Tallis's London street views, 1838-1840: Together with the revised and enlarged views of 1847 / introduced and with a biographical essay by Peter Jackson. (2nd rev. ed., Publication (London Topographical Society); no. 160). Richmond]: London Topographical Society. Retrieved From:

https://londontopsoc.org/product/joh n-talliss-london-street-views-1838-1840with-the-revised-and-enlarged-viewsof-1847/

The Universal Magazine of Knowledge and Pleasure. (1747). Vol: XX, London: according to Act of Parliament, for John Hinton, 1747. Retrieved From: https://catalog.hathitrust.org/Record/0 06791518

Willis, N. (1854). Famous Persons and Places. New York: Alden and Beardsley. Retrieved From: http://access.bl.uk/item/viewer/ark:/8 1055/vdc 100022591634.0x000001 \#? c= $0 \& \mathrm{~m}=0 \& \mathrm{~s}=0 \& \mathrm{cv}=0 \& \mathrm{xywh}=-1214 \% 2 \mathrm{C}-$ $105 \% 2 C 3565 \% 2 C 2081$

Figures:
Anonymous. (1802) A new Plan of London. URL 2 Retrieved on 2016-2017:

http://www.bl.uk/onlinegallery/onlinee x/crace/a/largeimage88484.html

Anonymous. (1828). Waterloo Place. URL 8, Retrieved on 2016-2017:

http://www.britishmuseum.org/researc h/collection_online/collection_object details/collection_image_gallery.aspx? assetld $=613534001$ \& objectld $=3205008$ \&partld=1

Anonymous. (1848). The Quadrant. URL 12 Retrived on 2016 -2017:

http://www.britishmuseum.org/researc h/collection online/collection object details/collection image gallery.aspx? assetld $=613504001$ \&objectld $=3204884$ \&partld=1

Anonymous. (1840-1850). No. 45 Regent Street. URL 11 Retrived on 2016- 2017:

http://www.britishmuseum.org/researc $\mathrm{h} /$ collection online/collection object details/collection_image_gallery.aspx? assetld $=613488001$ \&objectld $=3204872$ \&partld=1

Archer, JW. (1848). Deconstruction of the Quadrant. URL 13 Retrieved on 2016 2017:

http://www.britishmuseum.org/researc h/collection_online/collection_object details/collection_image gallery.aspx? assetld $=684738001$ \&objectld=3198829 \&partld=1 Ackermann. (1822). View in Regent Street, Piccadilly. URL 7 Retrieved on 2016-2017:

http://www.britishmuseum.org/researc h/collection_online/collection_object details/collection image_gallery.aspx? assetld $=613500001$ \&objectld $=3204888$ \&partld=1

Boys, TS. (1842). Regent Street, Quadrant. URL 5 Retrieved on 2016-2017:

http://www.britishmuseum.org/researc h/collection_online/collection_object details/collection_image_gallery.aspx? assetld $=819066001$ \&objectld $=3250830$ \&partld=1

Faden, W. (1814). Plan of a street. URL 3

Retrieved on 2016-2017:

http://www.bl.uk/onlinegallery/onlinee 
x/crace/p/007zzz000000012u00017000.

$\underline{\mathrm{html}}$

Heath, C. (1825). All Souls Church. URL 6

Retrieved on 2016-2017:

http://www.britishmuseum.org/researc

h/collection_online/collection_object

details/collection_image gallery.aspx?

assetld $=778018001$ \& objectld $=3250878$

\&partld=1

Locke ME. (2015). Modern Englishman Style of Brummel. URL 10 Retrived on 2016 -

2017: http://hfebooks.com/bath-timewith-beau-brummell-by-libi-astaire/

Sutherland T. (1817). Carlton House. URL 4

Retrieved on 2016-2017:

http://www.britishmuseum.org/researc h/collection_online/collection_object details/collection_image_gallery.aspx? assetld $=607623001$ \&objectld $=3206442$ \&partld=1

Tingle, J. (1827). St Philip's Chapel. URL 9, Retrived on 2016-2017:

http://www.britishmuseum.org/researc h/collection_online/collection_object details/collection_image gallery.aspx? assetld $=613527001$ \& objectld $=3204975$ \&partld=1

Webb, R., Toht, BD., (2001). Sewer system being installed in Piccadilly on Daily Life in Ancient and Modern London, p.43 Runestone Press, USA: Minneapolis. 
www.ijcua.com

This page is intentionally left blank. 